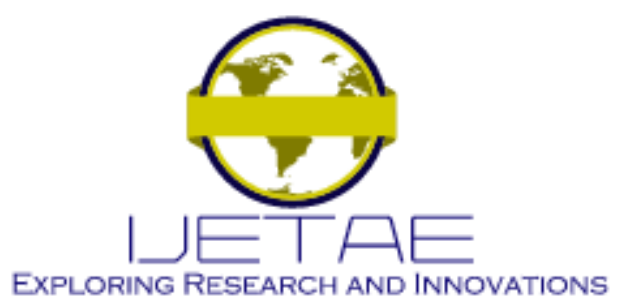

International Journal of Emerging Technology and Advanced Engineering

Website: www.ijetae.com (E-ISSN 2250-2459, Scopus Indexed, ISO 9001:2008 Certified Journal, Volume 11, Issue 12, December 2021)

\title{
Modern Information Technologies: Social Networks as a Modern Digital Marketing Tool for Hotel and Tourism Business
}

\author{
Elena M. Kryukova ${ }^{1}$, Valeria S. Khetagurova ${ }^{2}$ Liudmila I. Donskova $^{3}$, Pyotr V. Solodukha ${ }^{4}$, \\ Tatyana V. Fomicheva ${ }^{5}$, Julia O. Sulyagina ${ }^{6}$ \\ ${ }_{1,2,3,4,5,6}$ Russian State Social University, 4-1 Wilhelm Pieck str., Moscow, 129226, Russia.
}

\begin{abstract}
Lately, the tourism and hospitality industry has been actively developing. The high competition among travel agencies requires searching for new ways to promote travel services. Therefore, most commercial companies, including the tourism sector, use the Internet to promote their goods and services. The relevance of the research topic is caused by the fact that more and more people around the world use social networks. Therefore, in comparison with other platforms, social networks not only have a better global reach but also contain more information about users. This makes them a popular tool for manipulation. Manipulation in social networks consists in the application of several methods that use automation tools and certain algorithms of social networks.
\end{abstract}

Keywords - digital marketing technologies, the hospitality industry, information technologies, social media, tourism.

\section{INTRODUCTION}

The brisk growth of the information society, the globalization processes, and the smart economy necessitate the use of digital marketing. Any organization or company, at a certain stage of its performance, faces the problem of promoting its products or services. there is no universal promotion model suitable for all companies. This is because the same set of promotion tools can bring profit to one company, and losses to another. From this, it follows that each organization needs to select an individual promotion plan for its products or services and a certain set of tools that would contribute to increasing consumer interest [1].

In the modern world, the use of digital marketing is becoming increasingly relevant for organizations and companies in any field of activity. This is because digital marketing provides huge opportunities for entrepreneurs to promote their products and services.
The speed of making changes and the possibility of a detailed analysis of the advertising campaign, taking into account feedback and opinions of users, available on the Internet undoubtedly increase the competitiveness of companies in the contemporary economy. It has long been recognized that most of the population cannot imagine their life without the Internet It has long been recognized that most of the population cannot imagine their life without the Internet. About $62 \%$ of Russian residents cannot imagine their life without the Internet, and almost half of them feel uncomfortable without a smartphone. This is stated in the study of the National Payment Card System (NPCS, the operator of the Mir national payment system) [2]. Mobile devices allow providing round-the-clock access to any information anywhere in the world, which makes the use of digital marketing especially relevant [3-5].

The research topic is relevant because currently, more and more people around the world use social networks. Therefore, in comparison with other platforms, social networks not only have a better global reach but also contain more information about their users. This makes them a popular tool for manipulating the behavior of buyers when planning a purchase. Manipulation in social networks consists in the application of several methods that use automation tools and certain algorithms of social networks. A potential tourist is offered a vacation, new impressions, and in general, everything that cannot be touched or viewed before buying and, even more so, is impossible to save after. In this regard, manipulative technologies in social networks are used to convince a potential traveler of the high quality of the service provided, as well as its uniqueness and safety. Thus, the study of the capabilities of social networks as modern digital marketing tools in the hotel and tourism business seems promising both for improving business efficiency and developing the scientific component of studying the impact of various technologies on the buyer's decision-making process. 


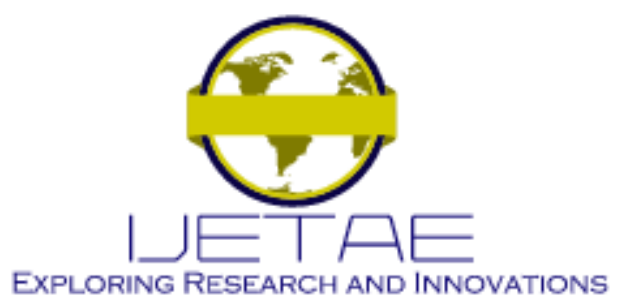

International Journal of Emerging Technology and Advanced Engineering

Website: www.ijetae.com (E-ISSN 2250-2459, Scopus Indexed, ISO 9001:2008 Certified Journal, Volume 11, Issue 12, December 2021)

The purpose of the present study is to develop recommendations on using manipulative technologies in social networks based on the example of the tourism and hospitality industry. According to the set goal, the following tasks were formulated: to consider the main modern digital marketing technologies; to analyze the impact of social networks and manipulative technologies used to promote hotel services; to offer recommendations on the using manipulative technologies in the promotion of hotel services.

\section{METHODS}

According to the stated purpose of the study, as well as certain tasks, the following methods were used: analysis of scientific and methodological literature, as well as general theoretical methods of collecting information, such as analysis, generalization, questionnaire, and synthesis. The research object was the information space of social media, and the research subject was the social manipulation phenomenon and its qualitative features in the sociocultural space of the information society of social media.

The purpose of the presented research is to study the features and abilities of social media for implementing manipulative technologies in the tourism and hospitality industry. The goal has defined the tasks, which concern studying modern digital marketing technologies, and the possibilities of social media in the implementation of manipulative technologies, as well as defining the specifics of these technologies in the hospitality industry.

To form a database of used sources, industry expert reviews, as well as statistical and marketing analytical reports of the social networks under consideration, are of key importance [6-14].

In the course of collecting the primary information required within the framework of this study, the survey method (questionnaire) was used.

This method is the most rational, due to its versatility, as well as the ease of processing the data obtained.

In the course of collecting the primary information, required within the framework of the present study, sociological research was conducted in May 2021 in Moscow and the Moscow Region, using an online questionnaire (closed questionnaire, the main sample included 300 respondents). Both Facebook and Instagram social media subscribers made up the study sample. The sample was target. The sample was not representative but qualitatively representative.
Subscription to social networks, such as Facebook, Instagram, VKontakte, etc., as well as using tourist services, were the criteria for the selection of respondents. Correlation and factor analysis of data was applied. Principles of generalization of results included linear, paired data distribution, and empirical classification. The data were processed using a statistical package for the social sciences (SPSS statistics).

The main objectives of the conducted survey are:

1) identifying the most frequently used social networks when planning trips;

2) assessing the degree of influence of social networks in the process of forming tourist preferences;

3 ) determining the impact of information received from social networks on the formation of tourists' desires and plans.

\section{RESULTS}

Advertising of tourist services is unique. This is because a potential tourist, after seeing the advertising, plunges into thoughts about the upcoming trip or forms an opinion about a certain country. Attractive offers of travel agencies, which are expressed in advertising nonverbally and verbally (photo, font, color scheme), can cause positive emotions in people. In this case, an example of manipulation is the posts on the social networks of the very hotels, travel agencies, or travel bloggers, having a hidden impact [15].

Every year, it becomes more difficult for hotels to compete, as well as stand out from the general background. This is due to the wide variety of proposed options presented on online platforms. Thus, one of the most important components in the successful performance of the hotel is the advantageous positioning of its brand in social networks. However, not all hotels use this resource effectively. Most often, hotels use large-scale advertising companies to attract consumers to book a room offline [16-25].

As part of the study on using manipulative technologies in social networks in tourism and hospitality, 300 questionnaires of potential consumers of this industry services were processed. The questionnaire contained eight closed questions. The results of the survey are analyzed below.

The structure of respondents according to their gender is as follows: $183(61 \%)$ were women and 117 (39\%) men. 


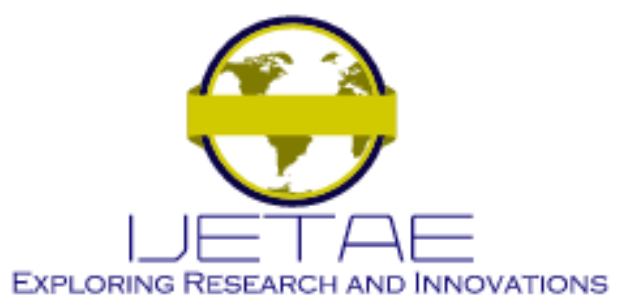

International Journal of Emerging Technology and Advanced Engineering

Website: www.ijetae.com (E-ISSN 2250-2459, Scopus Indexed, ISO 9001:2008 Certified Journal, Volume 11, Issue 12, December 2021)

According to the results obtained, the respondents can be divided into the following age groups: $29 \%$ were under 25 years old; $40 \%$ were from 26 to 35 years old; $21 \%$ - from 36 to 50 years old; and $10 \%$ - over 51 years old.

The least number of responses $(10 \%)$ was received from people over 51 years. At the same time, most of the responses were received from a group of people from 26 to
35 years old. According to the marital status, respondents were divided into the following groups: singles - 40\%; families with children $-25 \%$; and families without children $-35 \%$.

First, respondents answered the question "How often do you use the tourist market services?". The data obtained are shown in Figure 1.

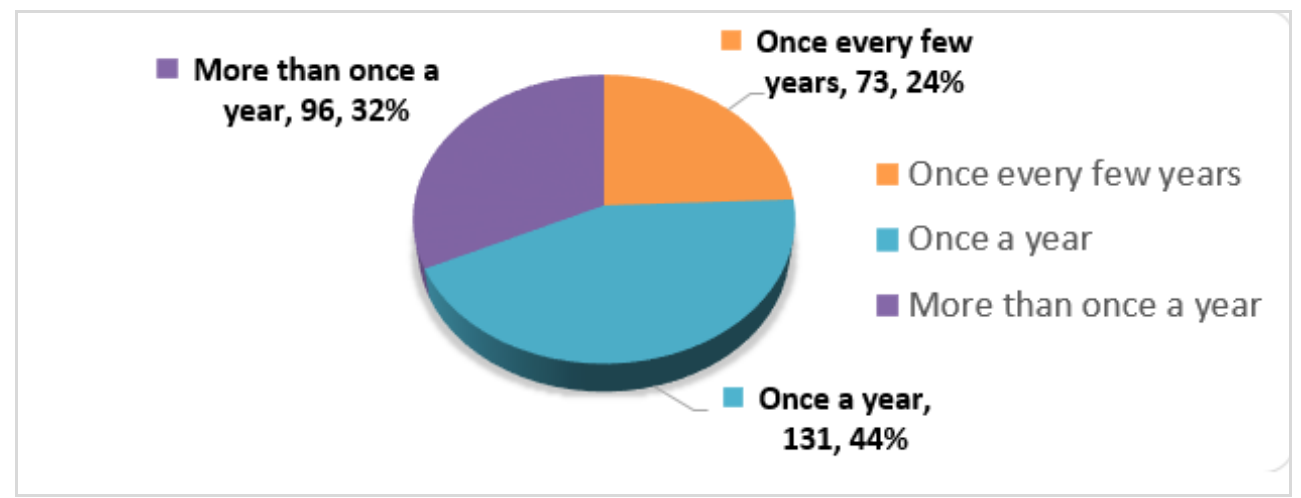

Figure 1. The answers to the question "How often do you use the tourist market services?"

Further, the respondents were asked to answer the question "What services of the tourist market do you use?"

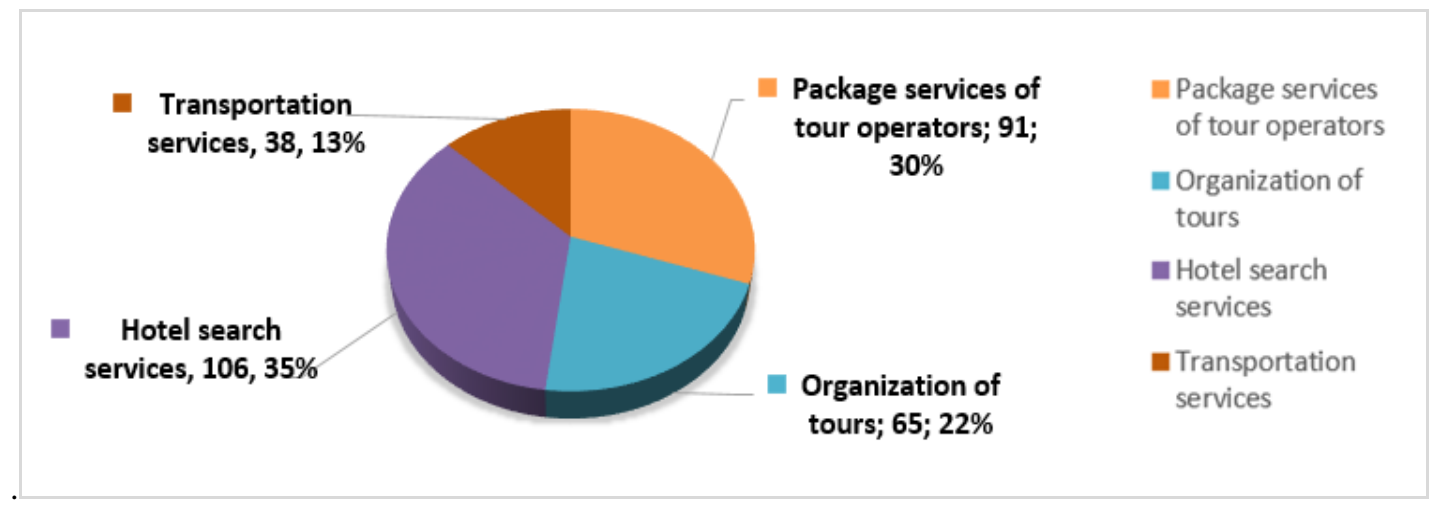

Figure 2. The answers to the question "What services of the tourist market do you use?"

Among the respondents, 104 (35\%) noted that they use the hotel business services. The smallest number of people use transport services $(13 \%)$.
Next, the respondents were asked to answer the question: "How do you search for hotels when planning a trip?". 


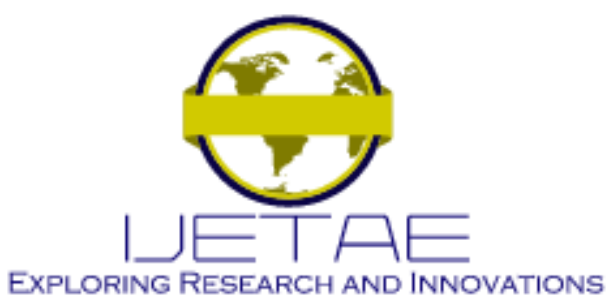

International Journal of Emerging Technology and Advanced Engineering

Website: www.ijetae.com (E-ISSN 2250-2459, Scopus Indexed, ISO 9001:2008 Certified Journal, Volume 11, Issue 12, December 2021)

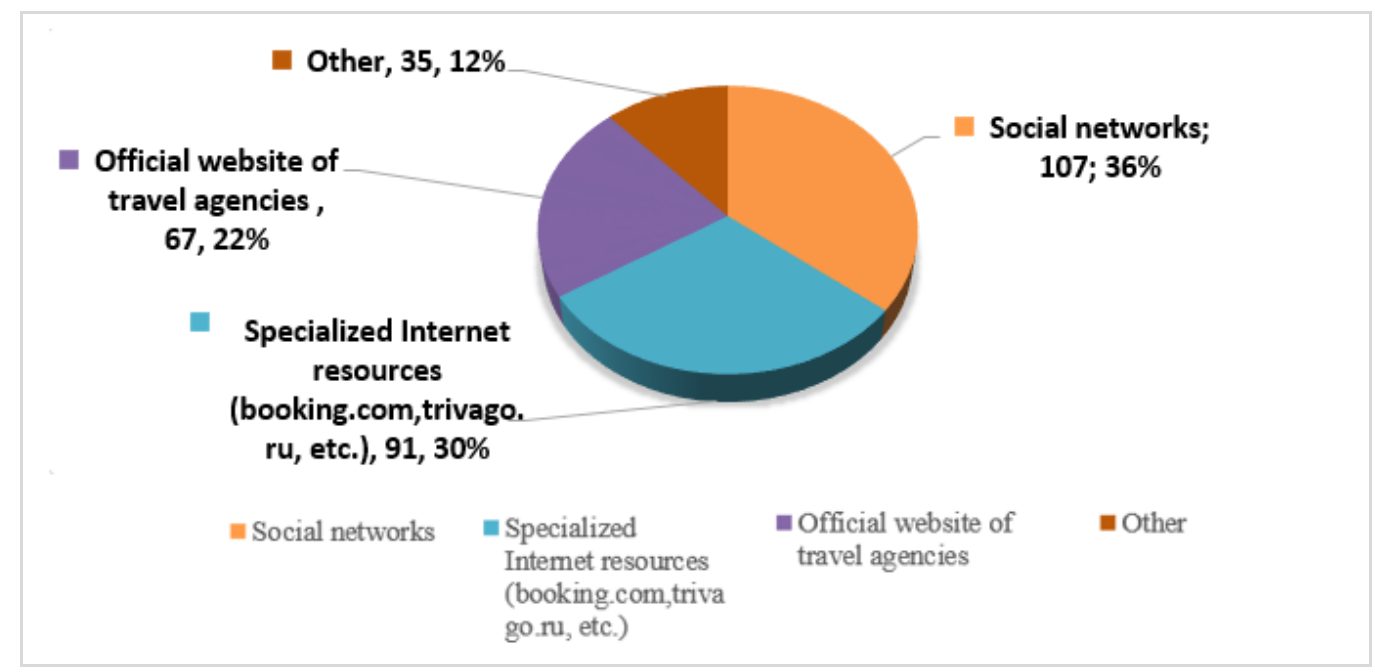

Figure 3. The answers to the question "How do you search for hotels when planning a trip?"

From the data presented in Figure 3, it can be concluded that when searching for a hotel, the majority of the respondents $(36 \%)$ use social networks. $30 \%$ of respondents prefer to search using specialized services like Booking.com, Trivago.ru, and others.
Further, the respondents were asked to answer the question: "What social networks do you use when searching for a hotel?". Most of the respondents, namely $43 \%$, use the social network Instagram to search for hotels. $26 \%$ of respondents use the social network VKontakte and $23 \%$ - Facebook. The obtained data are presented in Figure 4.

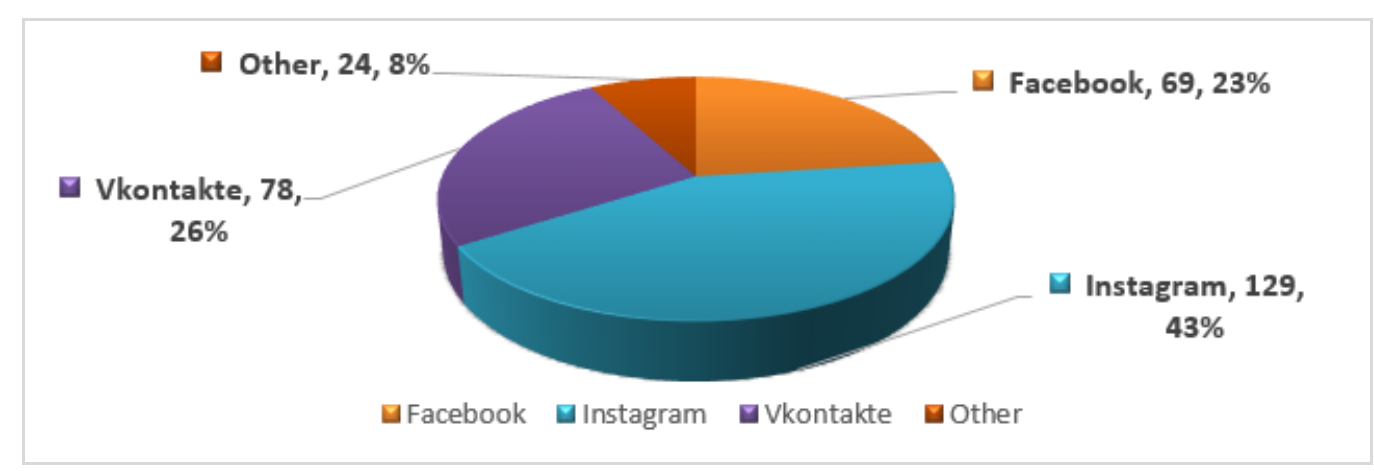

Figure 4. The answers to the question "Which social networks do you use when searching for a hotel?"

The next question allowed identifying what information sources respondents consider the most reliable. Corresponding data are shown in Figure 5. 


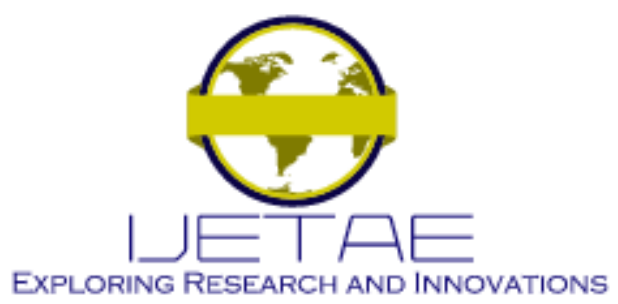

International Journal of Emerging Technology and Advanced Engineering

Website: www.ijetae.com (E-ISSN 2250-2459, Scopus Indexed, ISO 9001:2008 Certified Journal, Volume 11, Issue 12, December 2021)

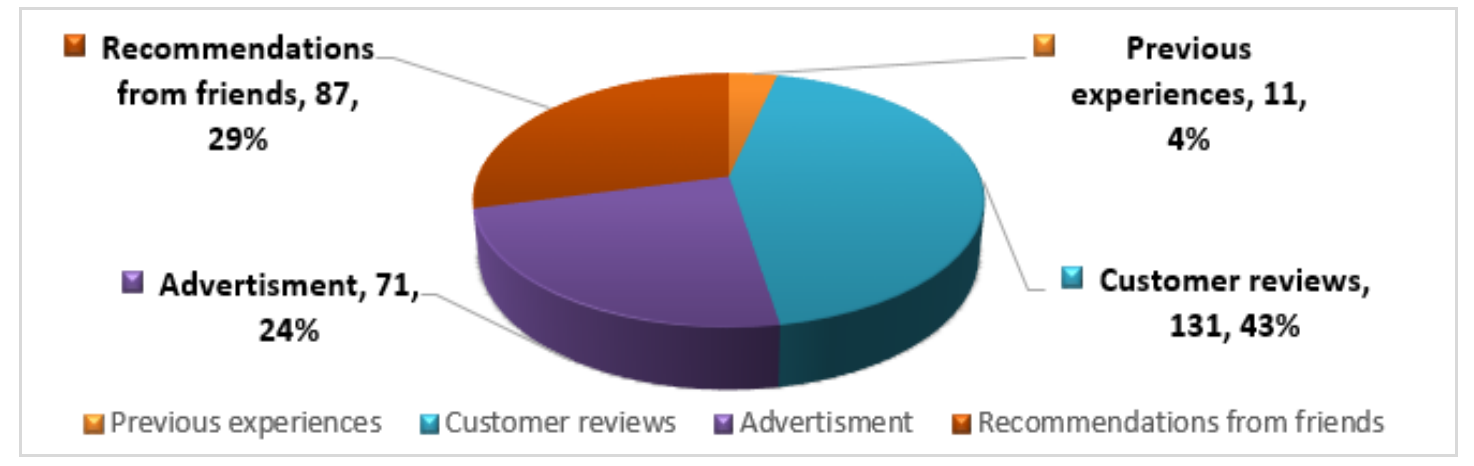

Figure 5. The answers to the question "What information sources are more reliable in your opinion when choosing a hotel?"

Thus, $43 \%$ of respondents believe that the most reliable information can be found in the reviews of previous guests. $29 \%$ of respondents listen to the advice and reviews of friends who have visited the hotel.
Next, the respondents were asked the question: "What do you pay attention to when viewing the social web page of a hotel?" (Figure 6).

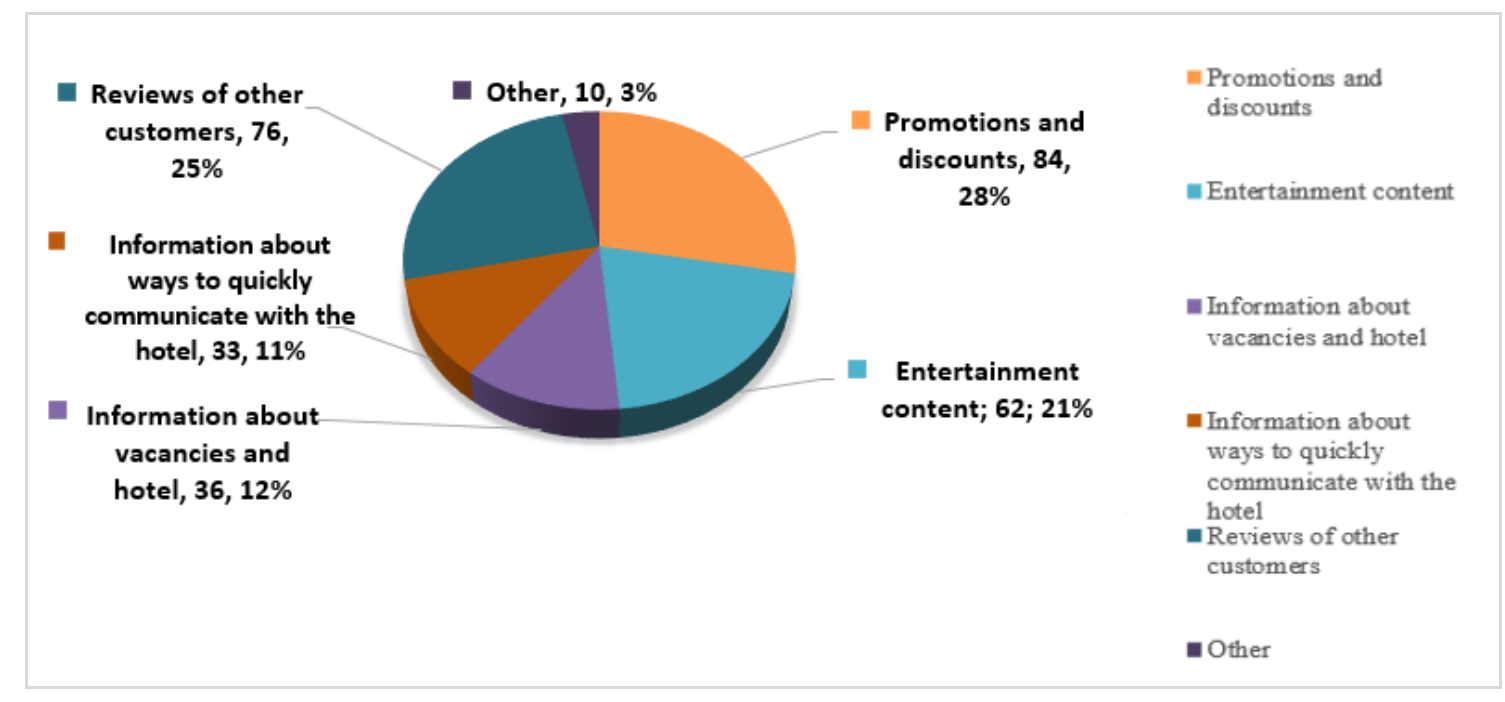

Figure 6. Answers to the question "What do you pay attention to when viewing the social web page of a hotel?"

From the data presented in Figure 6, it can be concluded that most of the respondents pay attention to promotions and discounts. At the same time, 25\% of respondents pay attention to the reviews. Entertainment content is a priority for $21 \%$ of respondents.
Further, the respondents were asked the question: "How often do you use promotional offers, presented on social networks?". The majority of respondents (39\%) replied that they rarely use promotional offers presented in social networks of hotels (Figure 7). 


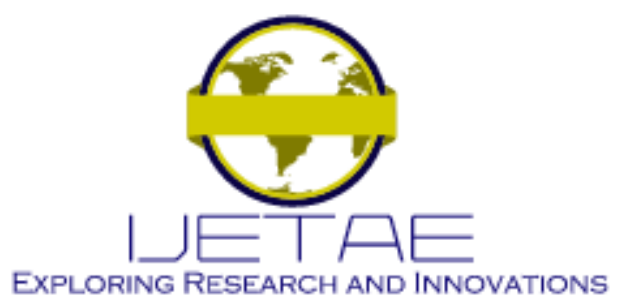

International Journal of Emerging Technology and Advanced Engineering

Website: www.ijetae.com (E-ISSN 2250-2459, Scopus Indexed, ISO 9001:2008 Certified Journal, Volume 11, Issue 12, December 2021)

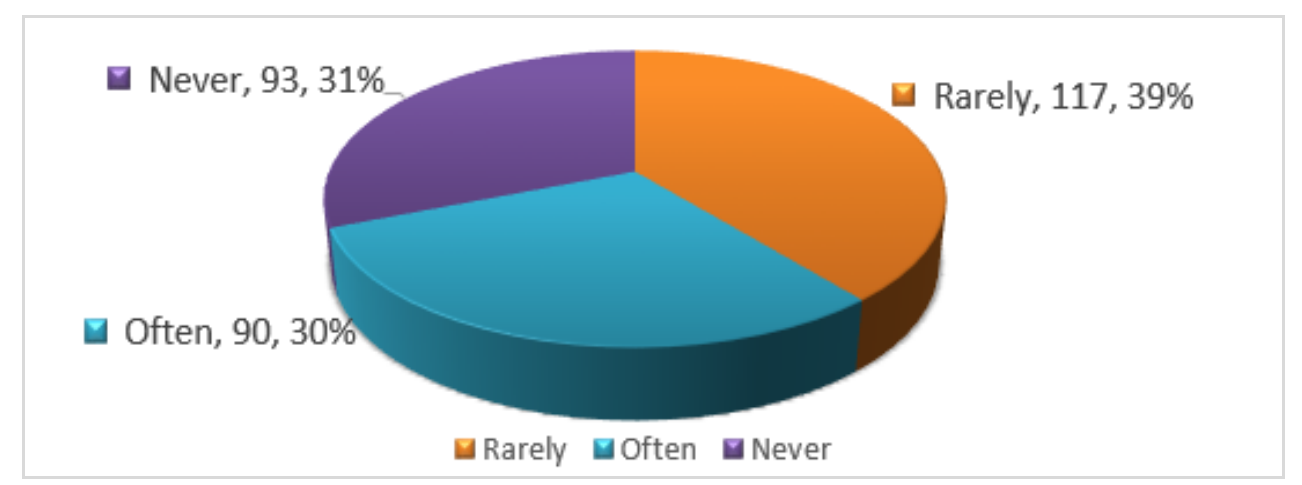

Figure 7. Answers to the question "How often do you use promotional offers presented on social networks?"

Finally, the respondents were asked to answer the question: "How do you learn about hotel promotions and offers (when using social networks?)". The answers received are shown in Figure 8.

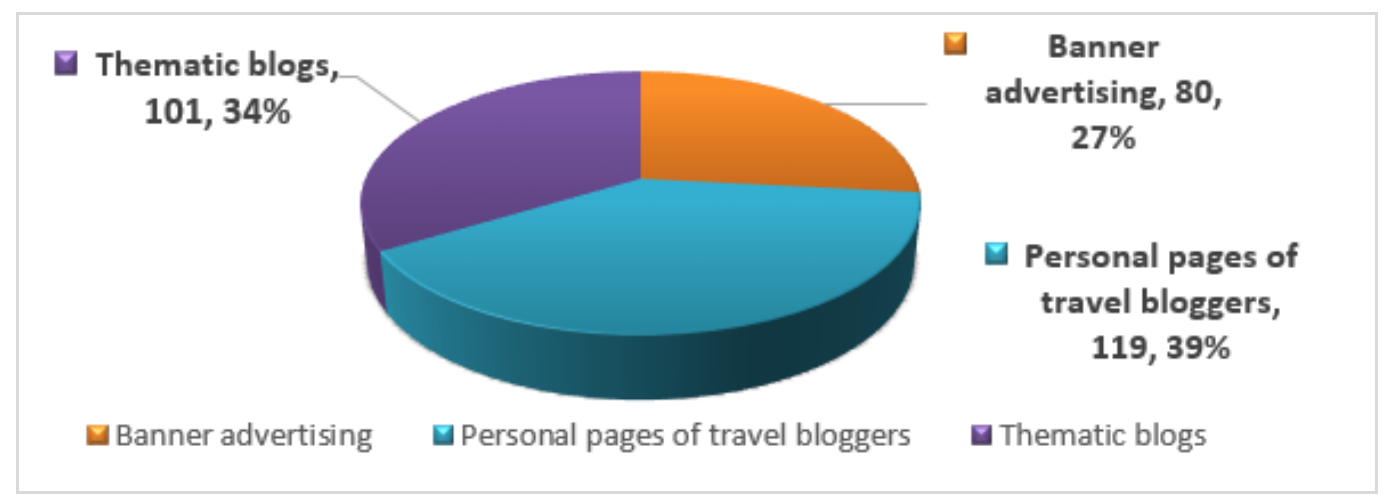

Figure 8. Answers to the question "How do you learn about hotel promotions and offers (when using social networks?)"

Thus, the majority of respondents $(39 \%)$ learn about promotional offers through the personal pages of travel bloggers. $34 \%$ of respondents learn about promotional offers from thematic blogs dedicated to travel.

The data obtained during the study allow drawing the following conclusions:

1) The majority of respondents prefer to use social networks when searching for a suitable hotel. Instagram is the preferred social network for receiving information from representatives of the hotel business. In terms of popularity, Vkontakte is in second place.

2) The popularity of Instagram is due to the potential consumers' age and preferences. An analysis of the responses received showed that $40 \%$ of respondents belong to the age category from 26 to 35 years. Thus, the majority of respondents belong to the millennial generation.
In choosing a hotel, they are characterized not only by the use of social networks in the search for a hotel but also by a preference for an interactive and simple interface, viewing images and videos. When choosing a hotel, millennials also tend to be guided by the opinions and reviews about the hotel of those people they follow on social networks. Instagram that meets all these requirements. This network is not only convenient in the placement of content but also allows arranging collaborations with bloggers and stars in a few clicks.

3) Most respondents learn about the promotional offers of the hotel from the personal web pages of travel bloggers. This suggests that hotels should be interested in collaborating with opinion leaders on social networks. At the same time, $39 \%$ of respondents rarely decide to take advantage of a favorable offer, while $31 \%$ of respondents do not use it at all. 


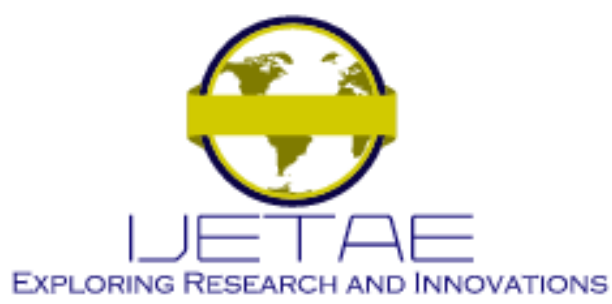

International Journal of Emerging Technology and Advanced Engineering

Website: www.ijetae.com (E-ISSN 2250-2459, Scopus Indexed, ISO 9001:2008 Certified Journal, Volume 11, Issue 12, December 2021)

Thus, social networks are a powerful tool for promoting hotel services. However, the hotel management should pay more attention to the interests and preferences of both regular and potential consumers.

Further, the analysis of social networks was carried out to study their use to increase competitiveness and attract the attention of potential customers. The leading positions in the promotion of hotel services are currently occupied by three social networks, namely, Twitter, Instagram, and Facebook [26]. According to a study conducted by the American company TravelClick, more than $65 \%$ of hoteliers use Facebook [27]. However, in the course of a study conducted earlier, it was revealed that among Russians the second most popular social network is VKontakte. In this regard, the official accounts of hotels in these social networks have been selected for analysis [14].

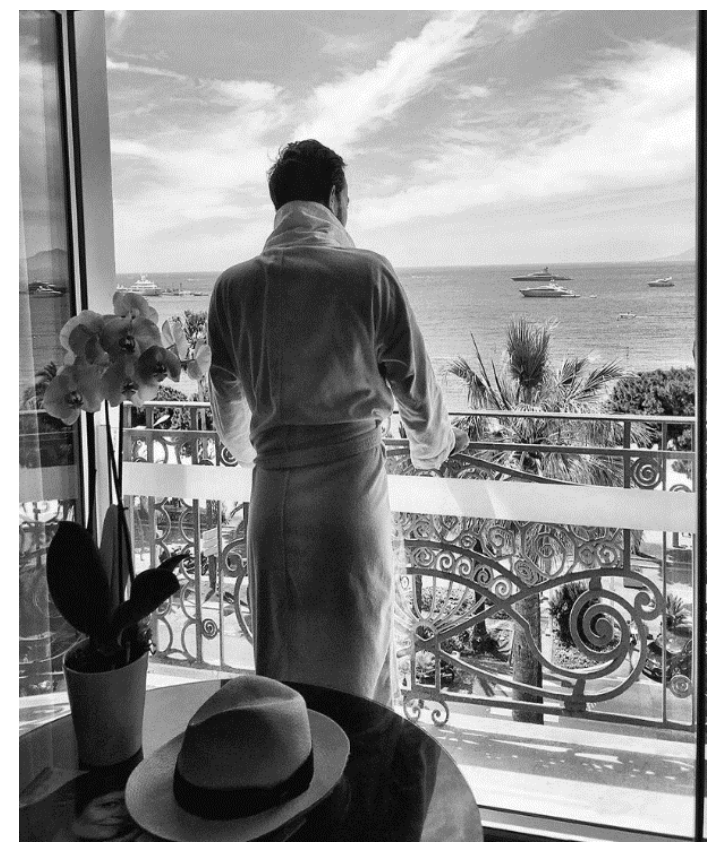

Figure 9. Example of a photo review of a hotel on Instagram

As can be seen from Figure 9, the permanent epithets, used in the description of the hotel perform a pictorial and evaluative function. A blogger, through their account, translates the image of a successful person, and a photo of an ideal vacation is like proof of a pre-written advertising text. In this case, the publication has one goal, namely, to convince the potential customer to choose a particular advertised hotel right now or in the future.

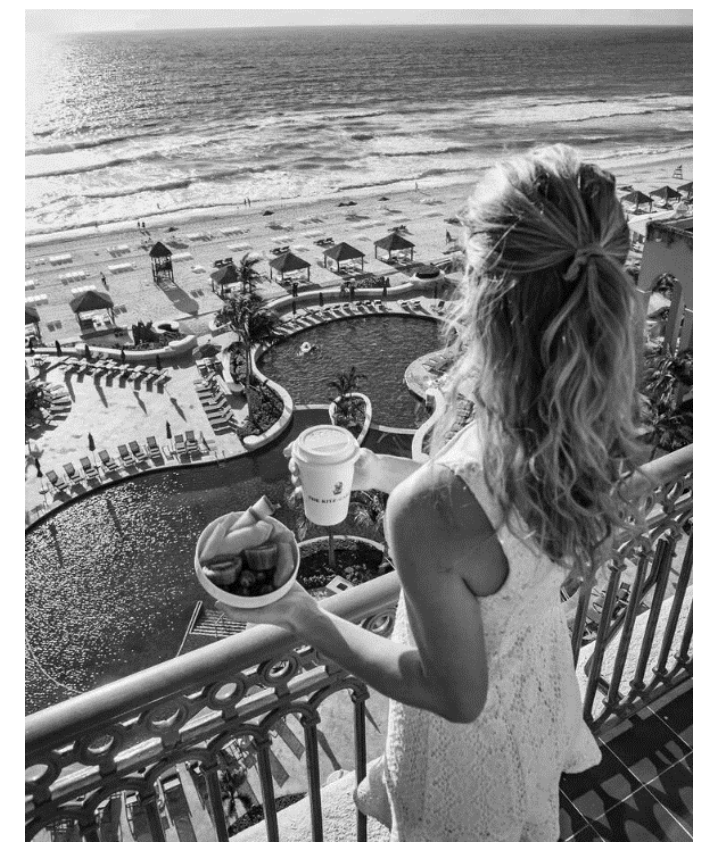

Analysis of hotel business enterprises' websites on Instagram showed that hotel enterprises actively cooperate with travel bloggers. Through their personal accounts, with a large number of subscribers, they broadcast the best photos of the hotel, as well as announcements of upcoming events. Their photos and posts-reviews about the impressions received, form a romantic mood among potential consumers, and also arouse curiosity and a desire to visit the specified hotel room or event.

In their posts, travel bloggers often mention the possibility of receiving certain promo code-based discounts [10]. This is another manipulation of hotel management. Potential visitors, having not recognized native advertising in the text, are more likely to use the promo code from the blogger. Let's consider an example of a post-review of a popular Russian blogger presented on the social network Instagram, shown in Figure 9.

A beautiful photo and expressive epithets can make the hotel advertising as native as possible, making it play on the feelings and emotions of potential consumers for a long time.

A feature of image manipulation through bloggers' accounts is the ability to create viral news. It is for this purpose that hoteliers create attractive images, catchy headlines, and profitable promotions in advance. 


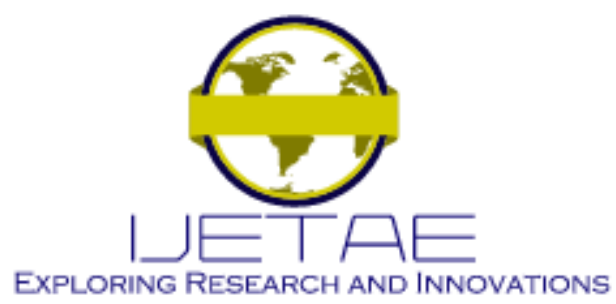

International Journal of Emerging Technology and Advanced Engineering

Website: www.ijetae.com (E-ISSN 2250-2459, Scopus Indexed, ISO 9001:2008 Certified Journal, Volume 11, Issue 12, December 2021)

Instagram and Facebook pages use speech and semiotic manipulations in addition to image manipulation through photos. Speech manipulation consists in a hidden influence on the addressee through language, i.e. using expressive epithets. Thus, speech manipulation is the use of appropriately constructed speech or special language tools.

An example of semiotic manipulation is the demonstration of figures (favorable prices, happy hours, discounts, etc.).
The price that attracts attention creates the impression of a low cost of the tour or a shortage of offers in general. just a few people pay attention to possible nuances in the form of emerging surcharges. After all, on the general background of a favorable price, such surcharges do not seem significant. Let's consider an example of semiotic manipulation on the thematic web pages of the hotel on these social networks (Figure 10).

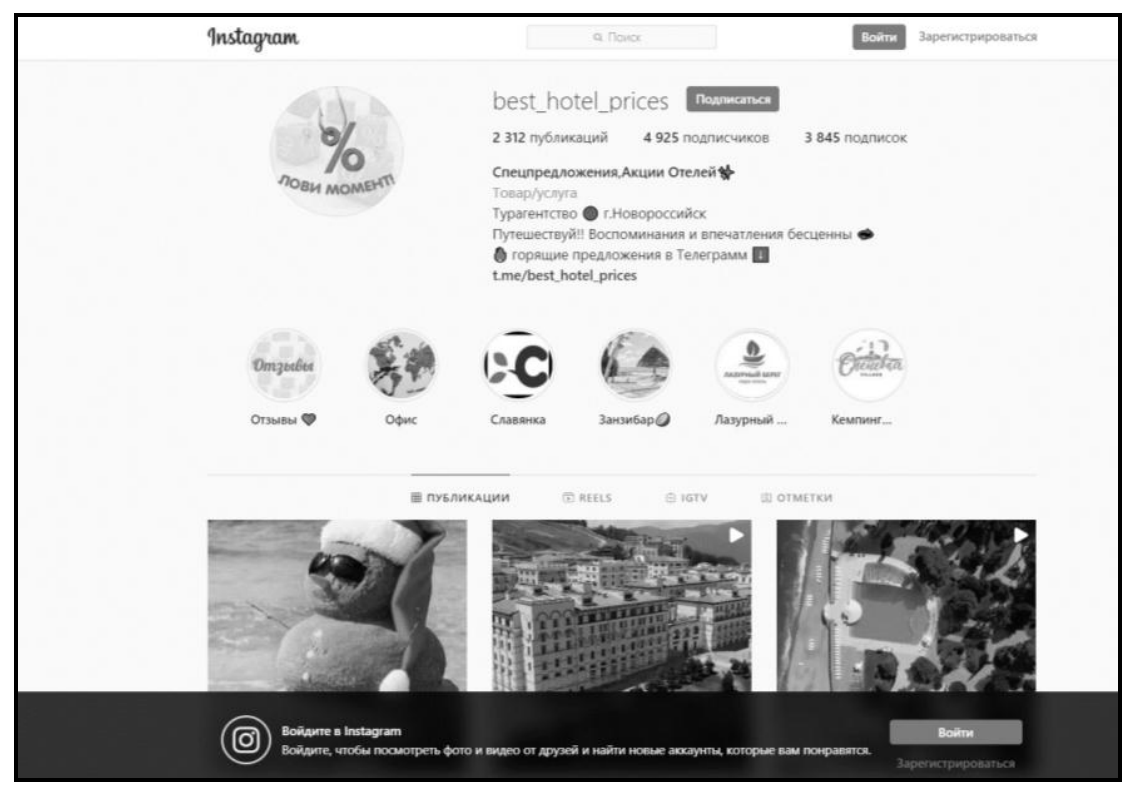

Figure 10. Example of hotel publications with semiotic manipulations

Note that the hotel also uses semiotic manipulation on its official website (Figure 10). 


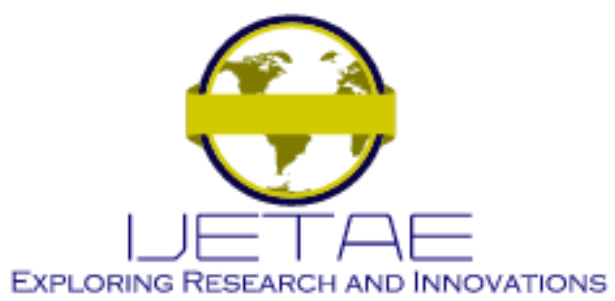

International Journal of Emerging Technology and Advanced Engineering

Website: www.ijetae.com (E-ISSN 2250-2459, Scopus Indexed, ISO 9001:2008 Certified Journal, Volume 11, Issue 12, December 2021)

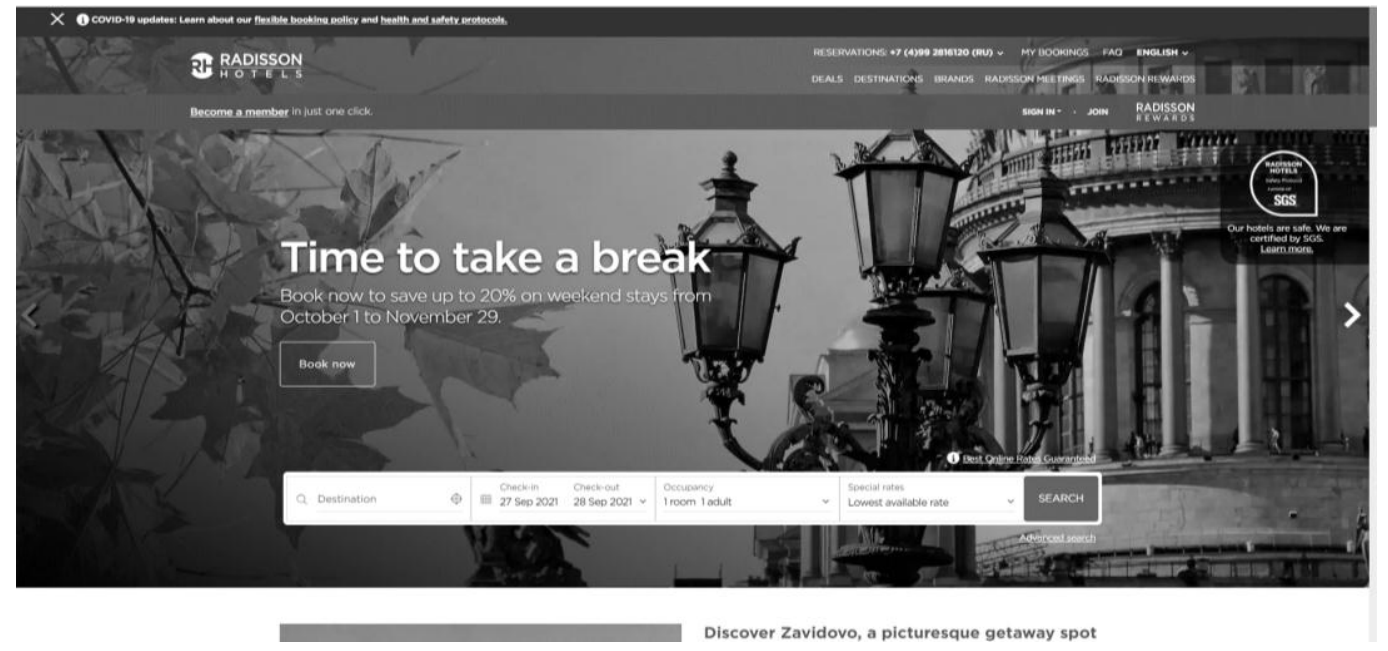

Figure 11. Example of the official website of the hotel

As can be seen from Figure 11, on its official website, the hotel uses tips that allow pushing a potential consumer to make a choice. Thus, when downloading the site, a popup window appears with an offer of a favorable promotion for booking a room at a favorable price "Favorable April$70 \% "$. the promotion also has a time limit, creating the illusion of a lack of supply.
Besides the manipulative technologies, used in social networks, the hotel uses the manipulative capabilities of a popular hotel accommodation booking site -Booking.com [6]. Such Internet resources allow consumers to quickly search for suitable accommodation, which in turn has a powerful impact on the promotion of hotel services. Such popularity of a unique service allows Booking.com to manipulate users with multiple techniques. Let's look at them in more detail shown in Figure 12.

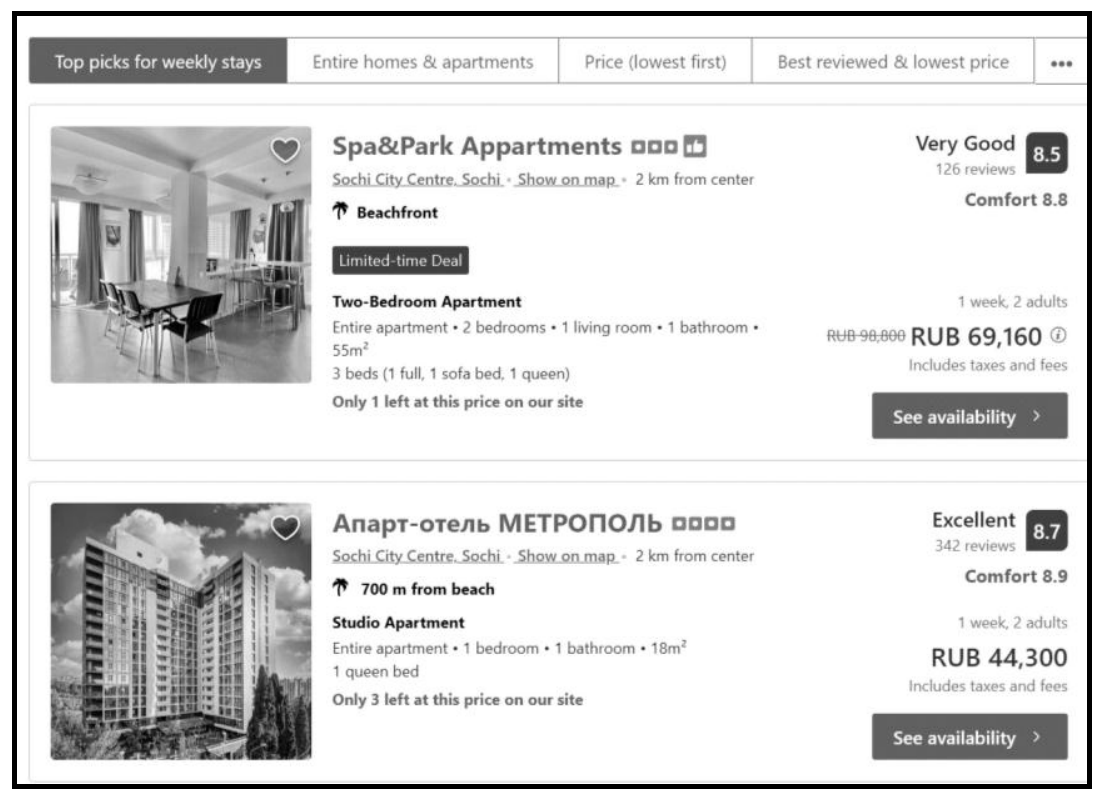

Figure 12. Web page for booking a hotel room on the Booking.com website [28] 


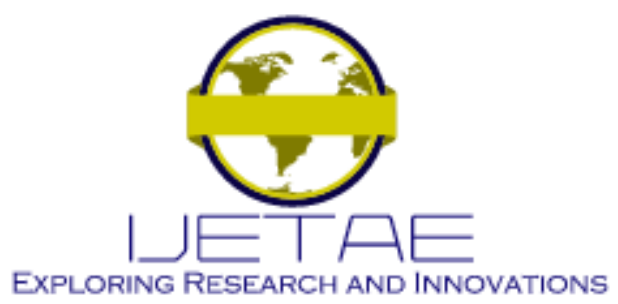

International Journal of Emerging Technology and Advanced Engineering

Website: www.ijetae.com (E-ISSN 2250-2459, Scopus Indexed, ISO 9001:2008 Certified Journal, Volume 11, Issue 12, December 2021)

As can be seen from Figure 12, the site Booking.com provides a complete overview of the availability of the hotel, number of rooms available, and offers a huge number of reviews. The portal actively demonstrates the idea of a shortage (limited supply), as well as a large demand (There is only one option left on our site at this price). Another manipulative technique is a warning that the price may increase significantly over time, and therefore it is most profitable to book a hotel room right now. One can also see crossed-out prices and impressive discounts on the site. This creates the impression that the bargain price offer is valid especially for you only here and now. However, this opinion is erroneous, since the current discounts are the result of an artificial and advanced overestimation of the price.

The study of manipulative technologies, used by hotel enterprises, as well as the analysis of social networks of hotels, allowed concluding most characteristic features of the hotel business, such as the absence of publication of reviews of tourists who visited this hotel on thematic pages on social networks, sporadic maintenance of thematic pages, in particular, on the VKontakte social network, which is a significant disadvantage in promoting hotel services in the Internet space, although that the VKontakte social network is used by more than $80 \%$ of Russianspeaking users, as well as the lack of unique content (the hotel needs to create unique content) which would be most suitable for a particular social network.

This is because each social network has its features and capabilities. It is worth it because different social networks have different audiences. Thus, according to a study by Deloitte, Facebook, Instagram, and VKontakte are preferred by the younger generation (from 16 to 29 years old), while Facebook is used by the older generation (more than 40 years old). Hoteliers do not pay enough attention to Instagram, which is the most promising for developing the hotel and promoting its services. Hoteliers also do not actively use chatbots, i.e. voice assistants, which allow not only quickly solving the arising issues but also providing personalized service to the visitor. Using a rather monotonous set of manipulative techniques, such as speech and semiotic manipulations, and image manipulation are not very effective. there are additional resources in social networks, such as Stories and IGTV, which hoteliers do not fully use.

\section{DISCUSSION}

Hidden influence techniques are often used when advertising tourist and hotel services. However, hotels began to use manipulation in social networks relatively recently. The peculiarity of the interaction between the consumer and the advertiser in the tourism and hospitality sector lies in a special relationship, where the recipient's response depends entirely on the communicative impression.

Image manipulation is most often used in advertising on social networks. This technique allows controlling the imagination of the addressee, forming the necessary need employing the right images. So, using social networks, travel companies make maximum efforts to form an image of a happy and successful person traveling around the world among consumers. In other words, advertising of travel agencies and hotels allows generating demand for an impersonally presented form of service through the introduction of the image of a socially successful person who regularly uses this service into potential consumers. in tourism and hospitality, manipulation techniques are very limited, they cannot have an aggressive form, cannot be repeated, and cannot contain direct deception of consumers. This is because the result of the use of manipulation in tourism always has a long-term perspective. The perception of the information received by the consumer has also changed. So, it has long been recognized that traditional ways of communicating with users are not successful. When people get open a hotel web page on social networks, they are reluctant to give feedback (in form of likes, comments, etc.) and do not feel the desire to participate in contests and offers that imply obtaining a gift in the form of a discount, which is confirmed by studies conducted by the Deloitte Research Center in the CIS countries "Media Consumption in Russia - 2019" [5].

Social media has long made it possible to build a fragment of a collective tourist picture of the world while using the experience presented on the network by other users. This allows tourists to picture the image of the destination and the selected hotel while relying on the reviews and comments of people who have been there before. According to a study conducted by World Travel Monitor, the influence of social networks, travel blogs, and forums on tourists is growing every year. Almost 500 thousand travelers from more than 60 countries of the world participated in the study sample. 


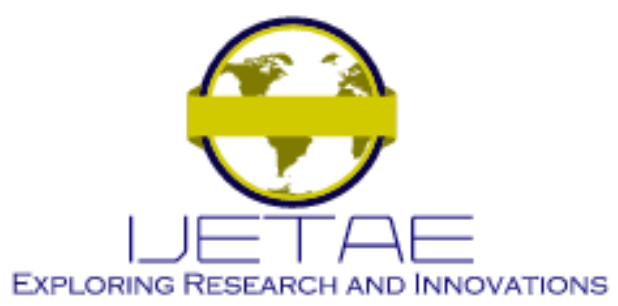

International Journal of Emerging Technology and Advanced Engineering

Website: www.ijetae.com (E-ISSN 2250-2459, Scopus Indexed, ISO 9001:2008 Certified Journal, Volume 11, Issue 12, December 2021)

More than $25 \%$ of respondents stated that when choosing the type and place of stay, their opinion is influenced by social networks. More than $75 \%$ noted that social networks are the main sources of tourist information for them. This is because potential tourists find vivid photos, stories, reviews, and other content, placed by other users on social networks. More than $50 \%$ of respondents trust the reviews of other travelers. The study also notes that older people generally avoid social networks when choosing a hotel, relying on the recommendations of travel agents [1, 29, 30]. According to the study conducted by the British company Knightsbridge Furniture, $83 \%$ of today's young people are ready to book a hotel room if they have seen photos on their friends' social media account. According to the same study, every third doubts that they will choose a hotel that is not registered on any of the social networks. The study surveyed 1,000 young people aged 18 to 35 years [7].

Manipulations have started being applied in tourism and hospitality relatively recently. However, the power of persuasive influence on the individual and mass consciousness of citizens continues to grow, shaping their tourist preferences. Nevertheless, the theoretical basis of this issue remains undisclosed. There are no unified approaches to the study of existing manipulative technologies developed by the humanities. An explanatory model of manipulative influence, as well as a classification of manipulative techniques, has not yet been developed. Therefore, it is impossible to give a direct economic or social assessment, which is primarily due to the lack of specific tools and indicators applicable in practice. However, the conducted research allows concluding that the developed recommendations are currently relevant, and their comprehensive application will allow achieving the greatest effect in the promotion of hotel services.

\section{CONCLUSION}

Thus, manipulative technologies are a set of techniques and tools that are used to influence the target audiences for their specific emotional programming. Performing simultaneously competitive and manipulative tasks, travel companies and hotels are forced to use a variety of manipulation means and techniques. due to the rapid saturation of consumer attention, to maintain the quality level of services provided, these techniques and means of manipulation must be constantly updated.
People's experiences and preferences regarding the services or goods they purchase are based not only on information obtained through corporate websites or other traditional media. As the survey results have shown, more and more often, their preferences are based on information and materials provided by subscribers of social networks. Currently, the presence of official web pages in social networks allows not only increasing the recognition of the hotel but also creating the hotel's in-house community, thereby increasing hotel competitiveness in the market. Consumers have long been accustomed to trusting the information available on the Internet. Therefore, the constant presence of the hotel in the lives of potential visitors makes it possible to increase its competitiveness.

\section{REFERENCES}

[1] D.M. Amet-Ustaeva, "Social networks as a tool for promoting tourist services", Young Scientist, no. 16(254), pp. 159-161, 2019. [Online]. Available: https://moluch.ru/archive/254/58345/ (date of access: February 5, 2021).

[2] I. Lobanova, More than $60 \%$ of Russians said that they could not imagine their life without the Internet, ITAR-TASS, April 7, 2021. [Online]. Available: https://news.rambler.ru/sociology/46168271/ ?utm_content=news_media\&utm_medium=read_more\&utm_source $=$ copylink

[3] N. Arkhipova, and M. Gurieva, "Modern trends in the development of digital marketing", Bulletin of the Russian State Humanities University. Series: Economics. Management. Right, no. 1(11), pp. 9$21,2018$.

[4] E.G., Yerlygina, and A.A. Yamanov, "The role of digital marketing in the system of market relations", Bulletin of Science and Practice, vol. 6 , no. 1 , pp. 248-252, 2020.

[5] Deloitte, Trends in the monetization of content on the Internet, Media consumption in Russia - 2019. Moscow, Russia: Research Center for Deloitte CIS, September 2019. [Online]. Available: https://www2.deloitte.com/content/dam/Deloitte/ru/Documents/tech nology-media-telecommunications/russian/mediaconsumptionrussia-2019.pdfhtml

[6] R. Cheplyaka, How Booking.com manipulates you, September 23, 2017. [Online]. Available: https://ro-che.info/articles/2017-09-17booking-com-manipulation (date of access: February 10, 2021).

[7] A. Tawns, Generation experience: attracting millennial hotel guests, November 23, 2018. [Online]. Available: https://www.knightsbridge-furniture.co.uk/2018/11/23/generationexperience-attracting-millennial-hotel-guests/

[8] "Millennials and how to influence them on social networks", Online platform for entrepreneurs and qualified professionals VC.RU, December 23, 2020. [Online]. Available: https://vc.ru/marketing/189864-milleniany-i-kak-na-nih-vliyat-vsocialnyh-setyah

[9] Official page of the Elitserp travel agency on Instagram. [Online]. Available: https://www.instagram.com/elitserp/ 


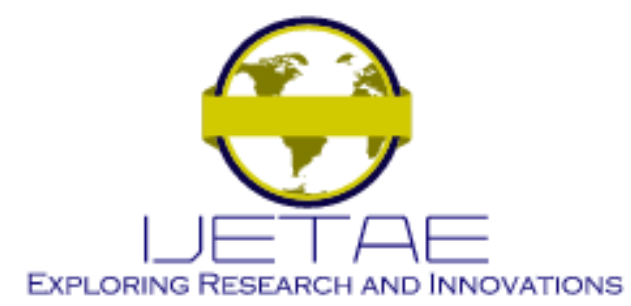

International Journal of Emerging Technology and Advanced Engineering

Website: www.ijetae.com (E-ISSN 2250-2459, Scopus Indexed, ISO 9001:2008 Certified Journal, Volume 11, Issue 12, December 2021)

[10] "How do bloggers manage public opinion around the world?" Professionals online magazine, May 14, 2018. [Online]. Available: https://professionali.ru/Soobschestva/biznes-klub/kak-blogeryupravljajut-obschestvennym (date of access: February 10, 2021).

[11] D. Baykov, Research: the impact of reviews on consumer opinion, November $11,2019 . \quad$ [Online]. Available: https://vc.ru/marketing/91417-issledovanie-vliyanie-otzyvov-namnenie-potrebitelya

[12] D.G. Evstafiev, "New socio-political protest and information and political manipulation technologies: 2017-2020 experience", Bulletin of Moscow State University, no. 4, pp. 46-65, 2020.

[13] J. Coney, Why the hotel booking website clampdown is long overdue, February 10, 2019. [Online]. Available: https://www.thetimes.co.uk/article/why-the-hotel-booking-websiteclampdown-is-long-overdue-67pdwbw7v

[14] "How social networks influence the choice of tourists", Bulletin of the Association of Tour Operators of Russia, March 11, 2016. [Online]. Available: https://www.atorus.ru/news/presscentre/new/34889.html (date of access: December 21, 2020).

[15] T.A. Beregovskaya, and S.A. Grishaeva, "Generation Z: Consumer behavior in the digital environment", Bulletin of the University, no. 1, pp. 92-99, 2020.

[16] S.V. Kalashnikova, and Z.A. Khanakhok, "The role of social networks in the promotion of hotel services", New Technologies, no. 1, pp. 262-269, 2019.

[17] E.M. Kryukova, and V.Sh. Khetagurova, "Modern methods and approaches to the management of the hotel services promotion", Revista Turismo Estudos and Práticas, no. S3, p. 2, 2020.

[18] V.S. Khetagurova, E.M. Kryukova, A.N. Maloletko, O.V. Kaurova, A.I. Mosalev, I.V. Mukhomorova, and E.N. Egorova, "Volunteer tourism as a variety of responsible tourism", Proceedings of the IOP Conference Series: Earth and Environmental Science, vol. 204, 012015, 2018. http://dx.doi.org/10.1088/1755-1315/204/1/012015

[19] A.I. Mosalev, E.M. Kryukova, I.V. Mukhomorova, E.N. Egorova, and V.S. Khetagurova, "Experience of socially responsible tourism projects in Russia", Proceedings of the IOP Conference Series: Earth and Environmental Science, vol. 204, 012030, 2018. http://dx.doi.org/10.1088/1755-1315/204/1/012030

[20] E. Kryukova, O. Kaurova, V. Khetagurova, and D. Makeeva, "Peculiarities of socially responsible tourism in Russia and prospects of its development", in A. Maloletko, N. Rupcic, and Z. Baracskai (Eds.), Proceedings of the IOP Conference on Economic and Social Development. Moscow, Russia: Russian State Social University, 2018, pp. 438-447.
[21] E. Kryukova, V. Khetagurova, A. Mosalev, I. Mukhomorova, and E. Egorova, "Organization of the use of Moscow cultural and historical heritage in tourist activities", Journal of Environmental Management and Tourism, vol. 10, no. 4, pp. 763-771, 2019.

[22] I. Ilina, A. Zotova, E. Kuznetsova, E. Nakhratova, and E. Kryukova, "Teachers of Russian higher educational institutions in the professional labor market", Rupkatha Journal on Interdisciplinary Studies in Humanities, vol. 8, no. 2, pp. 128-136, 2016. http://dx.doi.org/10.21659/rupkatha.v8n2.15

[23] S. Dusenko, A. Oleynik, V. Sharikov, V. Polyakov, E. Kryukova, and A. Melnichuk, "The current state of innovative activities in education: The Use of e-learning in Russian Universities", Research Journal of Pharmaceutical, Biological, and Chemical Sciences, vol. 7, no. 4, pp. 1629-1637, 2016.

[24] E. Drobyshev, O. Kaurova, and E. Kryukova, "Institutional structure and infrastructure of the tourism services market of Russia", in Proceedings of the $18^{\text {th }}$ International Scientific Conference on International Relations - Current Issues of World Economy and Politics, November 30 - December 1, 2017, Smolenice, Slovakia. Bratislava, Slovakia: Ekonom, 2017.

[25] E. Drobyshev, A. Maloletko, and E. Kryukova, "Evolution of the formation of market relations in the tourism industry", in Proceedings of the $18^{\text {th }}$ International Scientific Conference on International Relations - Current Issues of World Economy and Politics, November 30 - December 1, 2017, Smolenice, Slovakia. Bratislava, Slovakia: Ekonom, 2017.

[26] "Hotels promotion in social networks", Prohotel, June 18, 2011. [Online]. Available: http://prohotel.ru/news-157004/0 (date of access: December 20, 2020).

[27] "Hoteliers use social networks more actively", Hotel report, July 12, 2011. [Online]. Available: https://hotel.report/events/oteleryaktivnee-ispolzuyut-socialnye-seti

[28] Booking.com hotel booking website. [Online]. Available: www.booking.com/hotel/ru/the-rooms-hotel-moscow.ru.html (date of access: February 10, 2021).

[29] UNWTO. [Online]. Available: www.unwto.org (date of access: September 10, 2021).

[30] IPK International consulting company. [Online]. Available: https://www.ipkinternational.com/en/ ((date of access: September $10,2021)$. 